\title{
Quantitative study of mucosal structure, enzyme activities and phenylalanine accumulation in jejunal biopsies of patients with early and late onset diabetes ${ }^{1}$
}

\author{
E. O. RIECKEN, ${ }^{2}$ A. ZENNEK, A. LAY, AND H. MENGE \\ From the Medizinische Universitätsklinik, D-3500 Marburg/Lahn, Mannkopffstr. 1
}

SUMmARY A study of the three-dimensional structure of the upper jejunal mucosa in diabetics has been carried out. The structural findings were related to ${ }^{14} \mathrm{C}$-L-phenylalanine uptake in vitro, sucrase activity in mucosal homogenates, and the enzyme content of the absorptive cells as measured cytophotometrically. A low grade mucosal transformation of the sprue-type was found, which was associated with decreased sucrase activity, and with no reduction in phenylalanine accumulation. On the other hand the specific activities of alkaline phosphatase, non-specific esterase, and succinic dehydrogenase in the surface cells remained unchanged.

Numerous studies have shown that experimental diabetes mellitus in the rat is associated with structural changes in the small intestine (Jervis and Levin, 1966; Nakabou et al., 1974; Lorenz-Meyer et al., 1974, 1977), these being accompanied by functional alterations (Crane, 1961; Aulsebrook, 1965; Fromm et al., 1969; Levinson and Englert, 1970; Olsen and Rosenberg, 1970; Caspary, 1971; Olsen and Rogers, 1971; Schedl and Wilson, 1971; Younoszai and Schedl, 1972).

In the acute phase, an increase in the activities of brush border hydrolases and an enhanced absorption of actively transported hexoses and amino acids (Crane, 1961; Olsen and Rogers, 1971; Schedl and Wilson, 1971) has been reported. On the other hand, the mucosal histology remained unchanged in acute experimental diabetes mellitus (Schedl and Wilson, 1971).

In the chronic stage, structural modifications have been demonstrated in addition to altered function. The villi became hyperplasic and both cell proliferation and intestinal circumference increased (Nakabou et al., 1974; Lorenz-Meyer et al., 1974, 1977), leading to an enlargement of total absorptive surface (Lorenz-Meyer et al., 1977). Functionally, absorption is increased in vivo when related to total surface area and the accumulation of glucose, $\beta$ -

'Supported by the Deutsche Forschungsgemeinschaft (SFB 122).

${ }^{2}$ Address for reprint requests: Professor Dr. E. O. Riecken, Freie Universität Berlin, Universitäts-Klinicum Steglitz, Hindenburgdamm 30, D-1000 Berlin 45.

Received for publication 29 June 1979 methyl-glucoside, and of some actively transported amino acids in vitro is also stimulated (Crane, 1961; Olsen and Rosenberg, 1970; Schedl and Wilson, 1971; Lorenz-Meyer et al., 1977).

Compared with these studies in the experimental animal functional investigations in diabetic patients are scanty (Vinnik et al., 1965; Genel et al., 1971; Gottesbüren et al., 1973, 1974) and no morphological investigations of the small intestine have hitherto been presented, except in secondary diabetes due to pancreatic disease (Caspary et al., 1974). Glucose, water and electrolyte absorption was found by our own group to be unaltered in vivo according to the triple lumen tube technique (Gottesbüren et al., 1973), but an increase was reported in the studies of Vinnik and coworkers (1965). These authors, however, used unphysiologically high glucose concentrations in their test solution. In a further study, Genel et al. (1971) failed to show an increased glucose accumulation rate in vitro in small intestinal biopsies from diabetic patients.

The purpose of this investigation was to explore the mucosal structure of the jejunum in diabetic patients by three-dimensional quantitative analysis to find out whether changes occur in man similar to those seen in the chronic diabetic rat. In addition, phenylalanine absorption was measured in vitro and the activity of sucrase-a brush border marker enzyme-in whole homogenates of the biopsies was determined biochemically. Finally, the activities of alkaline phosphatase, succinic dehydrogenase, and non-specific esterase were measured cytochemically using microdensitometric methods. 
Methods

\section{SUBJECTS}

Seventeen diabetic patients without evident gastrointestinal disease were investigated; seven suffered from early onset diabetes and were treated with insulin, while the remaining 10 received either a diet alone or diet plus sulphonylurea-derivatives. At the time of investigation, the patients were all in a wellbalanced metabolic state and none suffered from exocrine pancreatic disease. The clinical data (body weight, diet, physical state, age, and the duration of diabetes mellitus) are given in Table 1. Twenty patients with an age range from 24 to 83 years served as controls. All these patients were without gastrointestinal disease (according to history, clinical examination, number, and aspect of faeces), and for three to four days before the investigation on a diet containing on average $160 \mathrm{~g}-200 \mathrm{~g}$ carbohydrates.

\section{JEJUNAL BIOPSIES}

After an overnight fast, specimens were obtained under radiological control from just beyond the ligament of Treitz by using Quinton's hydraulic multi-biopsy tube. Informed consent was obtained in each case.

Two pieces of mucosa, $5-15 \mathrm{mg}$ in weight, were fixed for microdissection as described by Clarke
(1970); two pieces were used for immediate determination of phenylalanine accumulation in vitro and two other pieces for the parallel determination of the extracellular space using ${ }^{14} \mathrm{C}$-polyethyleneglycol $(\mathrm{MW}=1000)$. Two pieces of tissue were shockfrozen in liquid nitrogen and stored at $-80^{\circ} \mathrm{C}$ in air-tight sealed plastic bags for biochemical and quantitative histochemical investigations respectively. Ancther biopsy was fixed in formalin and embedded in paraplast. Five $\mu \mathrm{m}$ sections were cut and stained with haematoxylin eosin for microscopic evaluation.

\section{MICRODISSECTION AND QUANTITATIVE}

ANALYSIS OF JEJUNAL MUCOSA

Three-dimensional quantitative analysis of the mucosal biopsies was done by adapting the microdissection technique of Clarke (1970) for human tissue as described earlier (Riecken et al., 1976). Briefly, the biopsies were fixed in three parts of ethanol and one part of glacial acetic acid for 24 hours; thereafter a Feulgen stain was done en bloc. The specimen was then photographed under the stereomicroscope to determine the number of villi per unit serosal area. Thereafter it was photographed upside down for the determination of the number of crypts per unit area. Consequently the thicknesses of at least 10 individual villi per specimen were measured under the stereomicroscope; the villi were then isolated, floated in Schiff's reagent on a cover glass,

Table 1 Diabetic patients-clinical data

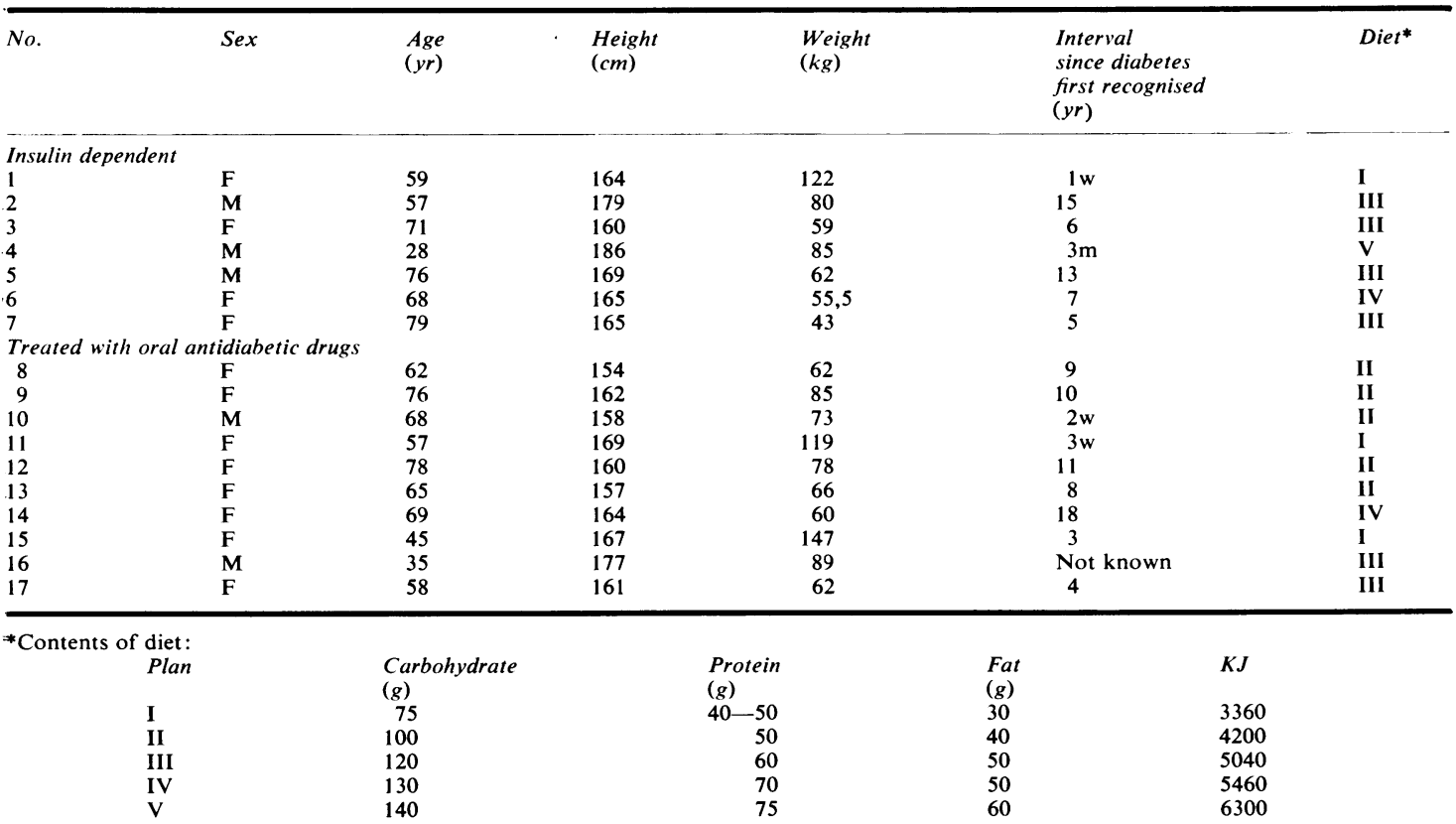


and photographed under the Orthoplan microscope. Total villus surface could then be calculated from the photographically determined area of the isolated villus and its circumference, as follows:

villus surface $=2 \times$ villus area + (villus - circumference $\times$ villus - thickness).

Finally, at least 10 crypts were isolated from 10 different villi of one specimen and the crypt length was measured under the stereomicroscope. The isolated crypts were floated on a slide and covered. Mitoses were counted under the microscope and given as counts per crypt.

In addition, the sections stained with haematoxylin and eosin were used to count the number of cells per $100 \mu \mathrm{m}$ villus column and crypt column and the epithelial cell height under the light microscope using an eye-piece graticule.

MEASUREMENT OF ${ }^{14} \mathrm{C}-\mathrm{L}-\mathrm{PHENYLALANINE-}$ ABSORPTION in vitro

The accumulation rate of ${ }^{14} \mathrm{C}$-L-phenylalanine in biopsies was determined in vitro according to the method of Robinson et al. (1964) and Beck et al. (1976). Measurements were carried out by incubating the tissue for 30 minutes at $37^{\circ} \mathrm{C}$ in a solution consisting of $1 \mathrm{mM}$ L-phenylalanine in Krebsbicarbonate buffer containing $11 \cdot 1 \mathrm{mM}$ glucose, to which $2 \mu \mathrm{Ci}{ }^{14} \mathrm{C}$-L-phenylalanine per $10 \mathrm{ml}$ was added. Counts were measured after lysis of the tissue with $30 \% \mathrm{KOH}$ in a Packard scintillation counter (type 3380). The extracellular space was determined using PEG (150 mg/10 ml) to which $2 \mu \mathrm{Ci}^{14} \mathrm{C}-\mathrm{PEG}$ per $10 \mathrm{ml}$ and $20 \mathrm{mg}$ glucose as a nutritional substance were added as above. Tissue uptake of phenylalanine was calculated from these data and expressed as nmol accumulated per $\mu$ intracellular space (ICR) assuming $80 \%$ tissue water.

DETERMINATION OF SUCRASE

This was done in the whole homogenates of the biopsy specimens, using the method of Dahlqvist (1964). Enzyme activity was expressed in terms of the protein content of the homogenate, measured by the method of Lowry et al. (1951).
DETERMINATION OF ENZYME ACTIVITIES IN INDIVIDUAL ENTEROCYTES

Frozen sections were used for cytochemical determination of alkaline phosphatase, succinic dehydrogenase, and non-specific esterase as described earlier (Lorenz-Meyer et al., 1977). The reaction products were quantified by measuring the optical density using a Leitz microdensitometer (MPV II) (Gutschmidt et al., 1978). The results were corrected for the thickness of the sections and the time of incubation for development of the reaction product (optical density/min $\times \mathrm{mm}$ ).

\section{STATISTICAL COMPARISONS}

Throughout, the $t$ test has been used.

\section{Results}

\section{MUCOSAL STRUCTURE}

\section{Microscopic appearance}

No clear-cut changes in the mucosal surface of diabetics were observed under the dissecting microscope when compared with the controls, but the villi seemed to be somewhat broader. There was no definite evidence of alterations in the zones of villi and crypts or of changes in the structure of the surface epithelium or of the round cells in the lamina propria.

\section{Morphometric evaluation}

The measurements as obtained from haematoxylineosin-stained sections are given in Table 2. The number of villus cells per unit length was significantly increased in the biopsies from the diabetic patients, while epithelial cell height was unchanged. The number of crypt cells per unit length was not different from the controls, though the crypt cell height was reduced.

The measurements performed on the microdissected biopsy specimens are given in Table 3 . Villus height was reduced and villus breadth increased in the diabetic mucosa, but this increase was not statistically significant. These data reflected

Table 2 Morphometric data $(\overline{\mathbf{x}} \pm S E M)$ : histology

\begin{tabular}{|c|c|c|c|}
\hline & $\begin{array}{l}\text { Diabetics } \\
(n=17)\end{array}$ & $\begin{array}{l}\text { Controls } \\
(n=20)\end{array}$ & $\begin{array}{l}\text { Statistical } \\
\text { comparison }\end{array}$ \\
\hline \multicolumn{4}{|l|}{ No. of cells per $100 \mu \mathrm{m}$} \\
\hline Crypt column & $29 \cdot 4 \pm 1 \cdot 25$ & $28.6 \pm 0.95$ & NS \\
\hline \multicolumn{4}{|l|}{ Height $(\mu \mathrm{m})$} \\
\hline Villus cells & $28.9 \pm 0.59$ & $28.4 \pm 0.36$ & NS \\
\hline Crypt cells & $15 \cdot 5 \pm 0 \cdot 26$ & $17 \cdot 4 \pm 0.59$ & $P<0.05$ \\
\hline
\end{tabular}

NS: not significant 
Table 3 Morphometric data $(\overline{\mathbf{x}} \pm S E M)$ : microdissection

\begin{tabular}{|c|c|c|c|}
\hline & $\begin{array}{l}\text { Diabetics } \\
(n=17)\end{array}$ & $\begin{array}{l}\text { Controls } \\
(n=20)\end{array}$ & $\begin{array}{l}\text { Statistical } \\
\text { comparison }\end{array}$ \\
\hline $\begin{array}{l}\text { Villi per unit area (no.) } \\
\text { Surface of individual villus }\left(\mathrm{mm}^{2}\right) \\
\text { Mucosal surface per unit serosal area }\left(\mathrm{mm}^{2} / \mathrm{mm}^{2}\right) \\
\text { Villus height }(\mu \mathrm{m}) \\
\text { Villus breadth }(\mu \mathrm{m}) \\
\text { Ratio of villus height to villus breadth } \\
\text { Crypt height }(\mu \mathrm{m}) \\
\text { Ratio of villus height to crypt length } \\
\text { No. of crypts per unit serosal area }\left(\mathrm{mm}^{2}\right)\end{array}$ & $\begin{array}{l}21 \cdot 9 \pm 1 \cdot 65 \\
0 \cdot 55 \pm 0.043 \\
11 \cdot 4 \pm 0 \cdot 84 \\
380 \pm 13 \cdot 8 \\
360 \pm 23 \cdot 7 \\
1 \cdot 2 \pm 0 \cdot 10 \\
165 \pm 5 \cdot 5 \\
2 \cdot 4 \pm 0 \cdot 18 \\
205 \pm 9 \cdot 7\end{array}$ & $\begin{array}{c}20 \cdot 8 \pm 1 \cdot 06 \\
0 \cdot 47 \pm 0.019 \\
11 \cdot 0 \pm 0.82 \\
437 \pm 10.7 \\
306 \pm 11 \cdot 0 \\
1 \cdot 5 \pm 0.07 \\
150 \pm 3 \cdot 9 \\
3 \cdot 0 \pm 0.16 \\
198 \pm 5 \cdot 9\end{array}$ & $\begin{array}{l}\text { NS } \\
\text { NS } \\
\text { NS } \\
P<0.05 \\
\text { NS } \\
P<0.025 \\
\text { NS } \\
P<0.025 \\
\text { NS }\end{array}$ \\
\hline
\end{tabular}

a change in villus shape from finger-like to broad leafy villi (as seen under the dissecting microscope). As a result, the ratio of villus height: villus breadth was significantly reduced in the diabetic mucosa (Table 3). There was a tendency towards an enlargement of the surface of the single villus but mucosal surface per unit area remained unchanged. Similarly, the number of villi and crypts per unit area was not statistically different between the two groups. Crypt length, on the other hand, was longer in the diabetic mucosa; although this difference was not significant, the altered height of the villus and crypt regions was convincingly reflected by a reduction in the ratio of the heights of villi and crypts $(\mathrm{P}<0.025)$ (Table 3$)$. These differences in morphometric findings were accompanied by a greater number of mitotic figures in the diabetic mucosa (Figure); this difference was most pronounced in the insulin-dependent group where the results differed significantly from those in the patients under oral antidiabetic drugs.

${ }^{14} \mathrm{C}$-L-PHENYLALANINE ACCUMULATION in vitro The accumulation rates of ${ }^{14} \mathrm{C}$-L-phenylalanine (expressed as the 'distribution ratios' of the substrate between intra- and extracellular water) were not statistically different (Table 4) between the two groups of mucosal biopsies.

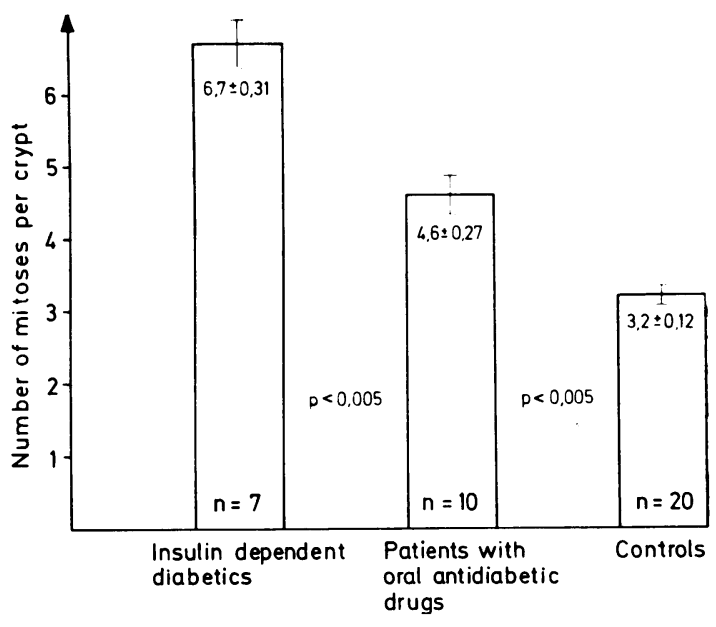

Figure Mitotic counts $\overline{\mathbf{x}} \pm S E M$

\section{ENZYME STUDIES}

The specific activity of sucrase in whole homogenates of mucosal biopsies was significantly lower in the diabetic group than in the controls (Table 4). On the other hand, the levels of alkaline phosphatase, succinic dehydrogenase, and non-specific esterase in the individual absorptive cells, assessed cytochemi-

Table 4 Biochemical and microdensitometric data $(\overline{\mathbf{x}} \pm S E M)$

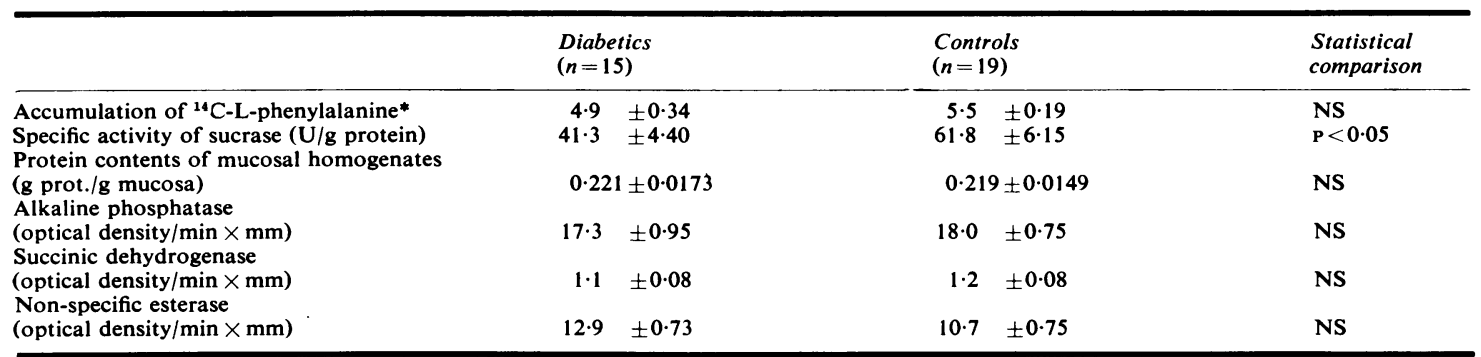

*Transport expressed as the ' distribution ratio' of the substrate between intracellular and extracellular water. 
cally, did not differ between diabetics and controls (Table 4). No difference was observed in the protein contents of the mucosal homogenates.

\section{Discussion}

The results of this study have shown that the human mucosal structure of the upper jejunum is distinctly altered in diabetes mellitus. It is characterised by a change in the shape of the villi with a reduction in villus height and an increase in villus breadth. Simultaneously, the crypts are slightly enlarged with a very marked increase in mitotic counts. As a result of this altered zoning of villi and crypts, the ratio of villus height: crypt length was significantly reduced. In addition, the increased number of epithelial cells per unit villus length revealed mucosal hyperplasia. Thus a low grade transformation of the mucosa has been shown and this was, as judged by the mitotic counts, more pronounced in insulindependent diabetics than in those who received oral hypoglycaemic drugs or simply maintained a diet.

Along with these morphological changes, a decreased sucrase activity in whole homogenates was observed. This change occurs characteristically in association with sprue-like pattern of the mucosa (Riecken and Martini, 1973; Menge et al., 1976) and is therefore in good agreement with the morphology but contrasts with the normal disaccharidase activities in human diabetes mellitus reported by others (Chaudhary and Olsen, 1973; Ruppin et al., 1974; Caspary et al., 1974). Alimentary influences as a cause of these differences are unlikely in view of the similar carbohydrate content of the food ingested by the control group. On the other hand, the enzyme contents of the individual cells as measured cytochemically were within the normal range in this investigation. Absorptive function as judged by ${ }^{14} \mathrm{C}$-L-phenylalanine accumulation in vitro tended to follow the decrease in sucrase activity, being slightly but not significantly reduced.

In contemplating these various findings, two major questions arise: first, how do these mucosal alterations compare with those occurring in the chronic experimental diabetic animal, and, second, what is the mechanism by which these changes are brought about? In chronic diabetes of the rat, analysis of jejunal structure and crypt cell kinetics has demonstrated an enlargement of the villi and an enhanced cell proliferation (Lorenz-Meyer et al., 1977). Similarly, the mucosa of the diabetic patients is characterised by increased mitotic counts, though this change is less pronounced in man than in the rat. This change in mitotic activity need not necessarily be associated with an increase in crypt length, as the region of mitotic activity may be expanded into the upper third of the crypt. In contrast with the animal model, however, the villi in the diabetic patients were not elongated but altered in shape with enlarged villus base and reduced villus height. Thus, in chronic diabetes of the rat, the mucosal response is quantitatively and qualitatively different from that seen in the upper jejunum of diabetic man.

When comparing these differences, it must be borne in mind that there are specific reasons which render difficult any comparison of diabetes in the experimental animal with that in man. The diabetic patients were in a well-balanced metabolic state at the time of investigation, while the diabetic rats were not. Blood sugar levels were well controlled in the patients but they were markedly increased in the animals. Nonetheless, an influence of a raised blood sugar level has so far been demonstrated only on mucosal function but not on structure; this was in acute experiments where continuous intravenous glucose infusion in the rat resulted in a significant increase in the mucosal-serosal flux-rate of glucose (Csáky and Fischer, 1977). On the other hand, no correlation was found between blood sugar levels and villus height (Lorenz-Meyer et al., 1977), whereas a positive correlation between food intake and villus height could be demonstrated. Furthermore, intestinal hyperplasia did not develop when the animals were only allowed normal food intake (Nakabou et al., 1974). From these experiments it is evident that the intestinal changes in the chronic diabetic rat result primarily from hyperphagia, which is very pronounced in chronic experimental diabetes and which has been shown to produce equivalent mucosal alterations in a number of different experimental conditions (Riecken and Menge, 1977). In the diabetic patients, on the other hand, a normal or low food intake was maintained.

Although these differences between diabetes in man and the experimental animal may explain the divergent adaptive responses of the small intestinal mucosa, the mechanism of the development of the mucosal transformation observed in diabetic patients remains speculative. A more or less pronounced sprue-pattern is usually associated with luminal stress due to a variety of damaging factors (Menge et al., 1977). An altered intestinal motility characteristic of human diabetes (McNally et al., 1969) could be associated with altered intestinal bacterial growth, but this has not been hitherto explored properly. However, bacterial overgrowth has been assumed in diabetic enteropathy on the basis of a therapeutic response due to tetracycline treatment (Malins and French, 1957).

Hormonal factors have also to be taken into account, among these hyperglucagonaemia, which is characteristic of diabetes mellitus. In fact, a sprue- 
like pattern has been produced in the rat on chronic application of glucagon at pharmacological doses (Lorenz-Meyer et al., 1977). Glucagon reduces intestinal motility (Nechelel et al., 1966) and markedly influences intestinal blood flow (Varró and Csernay, 1966) and could, in the long term, lead to bacterial overgrowth in the intestine of the diabetic and a consequent transformation of the mucosa.

Finally, an influence of antidiabetic drugs on intestinal structure and function must be considered. The effect of biguanides on intestinal function has been explored in man previously (Bloch et al., 1973) and no alterations in absorption and mucosal morphology have been detected. In this study the data were obtained, as in the present investigation, after an overnight fast. Similarly, no changes have been reported as a result of treatment with sulphonylurea-derivatives. Furthermore, the data between the diabetic patients on antidiabetic drugs and diet exclusively did not differ significantly. Thus oral antidiabetic medication along with insulin is very unlikely to be responsible for the observed changes, in view of the fact that insulin-dependent patients revealed the same or even a slightly more pronounced mucosal response as the patients under oral medication.

We are grateful to Professor R. N. Dowling, Guy's Hospital, London, and to Dr. J. W. L. Robinson (Département de Chirurgie Expérimentale CHUV, CH 1011 Lausanne) for critically reading the manuscript. Much of the work is taken from the MD theses of A. Zennek and A. Lay (Marburg).

\section{References}

Aulsebrook, K. A. (1965). Intestinal transport of glucose and sodium: changes in alloxan diabetes and effects of insulin. Experientia, 21, 346-347.

Beck, I. T., Dinda, P. K., Da Costa, L. R., and Beck, M. (1976). Sugar absorption by small bowel biopsy samples from patients with primary lactase deficiency and with adult celiac disease. American Journal of Digestive Diseases, 21, 946-952.

Bloch, R., Menge, H., Schaarschmidt, W. D., Gottesbüren, H., Schaumlöffel, E., Goebell, H., and Riecken, E. O. (1973). Biochemische, histochemische, histologische und funktionelle Untersuchungen zur Phenforminwirkung auf die Dünndarmschleimhaut bei Ratte und Mensch. Klinische Wochenschrift, 51, 235-241.

Caspary, W. F. (1971). Increase of digestive and transport functions of intestinal mucosa from steptozotocin diabetic rats. European Journal of Clinical Investigation, 2, 278 abstract.

Caspary, W. F., Winkler, K., and Creutzfeldt, W. (1974). Intestinal brush border enzyme activity in juvenile and maturity onset diabetes mellitus. Diabetologia, 10, 353-355.

Chaudhary, M. A., and Olsen, W. A. (1973). Jejunal disaccharidase activity in maturity onset diabetes. American Journal of Digestive Diseases, 18, 199-200.

Clarke, R. M. (1970). Mucosal architecture and epithelial cell production rate in the small intestine of the albino rat. Journal of Anatomy, 107, 519-529.

Crane, R. K. (1961). An effect of alloxan-diabetes on the active transport of sugars by rat small intestine invitro. Biochemica et Biophysica Research Communication, 4, 436-440.

Csáky, T. Z., and Fischer, E. (1977). Induction of an intestinal epithelial sugar transport system by high blood sugar. Experientia, 33, 223-224.

Dahlquist, A. (1964). A method for assay of intestinal disaccharidases. Analytical Biochemistry, 7, 18-25.

Fromm, D., Field, M., and Silen, W. (1969). Effect of insulin on sugar and amino acid transport across isolated small intestine. American Journal of Physiology, 217, 53-57.

Galjaard, H., and Bootsma, D. (1969). The regulation of cell proliferation and differentiation in the intestinal epithelium. 2. A quantitative histochemical and autoradiographic study after low doses of $x$-irradiation. Experimental Cell Research, 58, 79-92.

Genel, M., London, D., Holztapple, P. G., and Segal, S. (1971). Uptake of alpha-methylglucoside by normal and diabetic human jejunal mucosa. Journal of Laboratory and Clinical Medicine, 77, 743-750.

Gottesbüren, H., Leising, H., Menge, H., Lorenz-Meyer, H., and Riecken, E. O. (1974). Einflu B von Glucagon auf die Glucose-, Wasser- und Elektrolyt-Resorption des menschlichen Jejunums. Klinische Wochenschrift, 52, 926-929.

Gottesbüren, H., Schmitt, E., Menge, H., Bloch, R., Lorenz-Meyer, H., and Riecken, E. O. (1973). Untersuchungen zum Einflu $B$ des Insulins auf die intestinale Resorption beim Menschen. Research in Experimental Medicine, 161, 262-271.

Gutschmidt, S., Lorenz-Meyer, H., Riecken, E. O., and Menge, H. (1978) Mikrodensitometrische Untersuchungen zur Charakterisierung von Enzymaktivitäten am Gewebsschnitt mittels enzymhistochemischer Farbreaktionen. Acta Histochemica (Jena), suppl. XX, 249-259.

Jervis, E. L., and Levin, R. J. (1966) Anatomic adaptation of the alimentary tract of the rat to the hyperphagia of chronic alloxan-diabetes. Nature (London), 210, 391-393.

Levinson R. A., and Englert, E. Jr. (1970). Intestinal absorption of sugars, water and sodium in alloxandiabetic rats. Diabetes, 19, 683-687.

Lorenz-Meyer, H., Gottesbüren, H., Menge, H., Bloch R., and Riecken, E. O. (1974). Intestinal structure and function in relation to blood-sugar levels and food intake in experimental diabetes. In Intestinal Adaptation, pp. 189-191. Edited by R. H Dowling and E. O. Riecken. Schattauer-Verlag: Stuttgart.

Lorenz-Meyer, H., Menge, H., and Riecken, E. O. (1977). Untersuchungen zur Funktion und Morphologie der Dünndarmschleimhaut der Ratte unter chronischem Glukagoneinflu ß. Research in Experimental Medicine, 170, 181-192.

Lorenz-Meyer, H., Thiel, F., Menge, H., Gottesbüren, H., 
and Riecken, E. O. (1977). Structural and functional studies on the transformation of the intestinal mucosa in rats with experimental diabetes. Research in Experimental Medicine, 170, 89-99.

Lowry, O. H., Rosebrough, N. J., Farr, A. L., and Randall, R. J. (1951) Protein measurement with the folin phenol reagent. Journal of Biological Chemistry, 193, 265-275.

Malins, J. M., and French, J. M. (1957). Diabetic diarrhoea. Quarterly Journal of Medicine, 26, 467-480.

McNally, E. F., Reinhard, A. E., and Schwartz, P. E. (1969). Small bowel motility in diabetics. American Journal of Digestive Diseases, 14, 163-169.

Menge, H., Robinson, J. W. L., and Mirkovitch, V. (1977). Influence of the colonic contents on the structure and function of the rat jejunal mucosa. Experimental Molecular Pathology, 26, 204-213.

Menge, H., Robinson, J. W. L., and Riecken, E. O. (1976). Anpassungsmöglichkeiten der Dünndarmschleimhaut an verschiedene intraluminale Milieuveränderungen. Zeitschift fur Gastroenterologie, 14, 420-433.

Nakabou, Y., Okita, C., and Takano, Y., et al. (1974). Hyperplastic and hypertrophic changes of the small intestine in alloxan diabetic rats. Journal of Nutrition Science and Vitaminology, 20, 227-234.

Nechelel, H., Sporn, J., and Walker, L. (1966). Effect of glucagon on gastrointestinal motility. American Journal of Gastroenterology, 45, 34-40.

Olsen, W., and Rogers, L. (1971). Jejunal sucrase activity in diabetic rats. Journal of Laboratory and Clinical Medicine, 77, 838-842.

Olsen, W. A., and Rosenberg, I. H. (1970). Intestinal transport of sugars and amino acids in diabetic rats. Journal of Clinical Investigation, 49, 96-105.

Riecken, E. O., and Martini, G. A. (1973). Die Klassifizierung pathologischer Dünndarmschleimhautbilder.
Deutsche Medizinische Wochenschift, 98, 998-1004.

Riecken, E. O., and Menge, H. (1977). Nutritive effects of food constituents on the structure and function of the intestine. Acta Hepato-Gastroenterologica, 24, 389-399.

Riecken, E. O., Sahlfeld, M., and Lorenz-Meyer, H. (1976). Quantitative Untersuchungen zur dreidimensionalen Struktur der Dünndarmschleimhaut bei Gesunden und Patienten mit einheimischer Sprue. Deutsche Medizinische Wochenschrift, 101, 51-53.

Riecken, E. O., Stewart, J. S., Booth, C. C., and Pearse, A. G. E. (1966). A histochemical study of the role of lysosomal enzymes in idiopathic steatorrhoea before and during a gluten-free diet. Gut, 7, 317-332.

Robinson, J. W. L., Taminelli, F., Felber, J. P., and Magnenat, P. (1964). In vitro measurement of aminoacid uptake by the human small intestine. Medicina Experimentalis (Basel), 10, 157-163.

Ruppin, H., Domschke, W., Domschke, S., and Classen, M. (1974). Intestinale Disaccharidasen bei juvenilem Diabetes mellitus. Klinische Wochenschrift, 52, 568-570.

Schedl, H. P., and Wilson, H. D. (1971). Effects of diabetes on intestinal growth and hexose transport in the rat. American Journal of Physiology, 220, 1739-1745.

Schedl, H. P., and Wilson H. D. (1971). Effect of diabetes on intestinal growth in the rat. Journal of Experimental Zoology, 176, 487-496.

Varró, V., and Csernay, L. (1966). The effect of intraarterial insulin and glucagon on the glucose metabolism of the small intestine in the dog. Scandinavian Journal of Gastroenterology, 1, 232-237.

Vinnik, J. E., Kern, F., Jr. and Sussman, K. E. (1965). The effect of diabetes mellitus and insulin on glucose absorption by the small intestine in man. Journal of Labc:ratory and Clinical Medicine, 66, 131-136.

Younoszai, M. K., and Schedl, H. P. (1972). Effect of diabetes on intestinal disaccharidase activities. Journal of Laboratory and Clinical Medicine, 79, 579-586. 